\title{
STOCHASTIC FRONTIER ANALYSIS ON TECHNICAL EFFICIENCY OF STRAWBERRY FARMING IN PURBALINGGA REGENCY INDONESIA
}

\author{
*Irene Kartika Eka Wijayanti \\ Program Study of Agribusiness of Faculty of Agriculture \\ Universitas Jenderal Soedirman \\ Jamhari, Dwidjono Hadi Darwanto, dan Any Suryantini \\ Faculty of Agriculture of Universitas Gadjah Mada \\ Submitted: 15-11-2018; Revised: 22-07-2019; Accepted: 30-07-2019
}

\begin{abstract}
ABSTRAK
Stroberi merupakan salah satu komoditas hortikultura yang memiliki nilai ekonomi tinggi sehingga sangat potensial sebagai sumber pendapatan petani. Stroberi adalah buah yang dapat dikonsumsi segar, beku, atau dibuat menjadi olahan. Permintaan stroberi di pasar internasional yang relatif tinggi sampai saat ini masih belum dapat terpenuhi. Kondisi ini memberikan peluang yang bagus untuk mengembangkan stroberi di Indonesia. Selama ini budidaya stroberi yang dilakukan oleh petani masih bersifat konvensional dan diusahakan dalam skala kecil. Berbagai aspek yang penting untuk menjaga kualitas buah tidak dilakukan dengan baik oleh para petani. Alokasi input yang bervariasi antar petani mengakibatkan terjadinya produksi yang tidak efisien Penelitian ini bertujuan untuk mengetahui efisiensi teknis usahatani stroberi dan factor-faktor yang mempengaruhi inefisiensi teknis usahatani stroberi di Kabupaten Purbalingga. Penelitian dilakukan di Kecamatan Karangreja, Kabupaten Purbalingga Propinsi Jawa Tengah. Penentuan sampel 100 petani stroberi dilakukan secara purposive dengan kriteria petani yang telah mengusahakan tanaman stroberi minimal tiga tahun berturut-turut mulai tahun 2015 hingga 2017. Analisis data yang digunakan untuk mengukur efisiensi teknis dan factor yang mempengaruhi inefisiensi teknis adalah fungsi produksi Stochastic Frontier. Hasil penelitian menunjukkan bahwa usahatani stroberi di Kabupaten Purbalingga Propinsi Jawa Tengah secara teknis telah efisien dalam kisaran yang bervariasi antara 26,50 - 99,40 persen dengan rata-rata 77,80 persen. Variabel yang berpengaruh nyata terhadap inefisiensi teknis stroberi adalah pendidikan formal petani dan jumlah anggota rumah tangga. Untuk meningkatkan nilai efisiensi usahatani stroberi diperlukan perbaikan pengetahuan dan ketrampilan petani melalui penyuluhan, pendampingan, dan pelatihan untuk meningkatkan kemampuan petani dalam mengelola usahanya secara professional, efisien, dan berjiwa wirausaha. Pendampingan dapat diberikan secara berkelompok oleh pihak pemerintah, swasta, maupun perguruan tinggi.
\end{abstract}

Kata Kunci: Efisiensi Teknis; Kabupaten Purbalingga; Stochastic Frontier; Usahatani Stroberi.

${ }^{*}$ Corresponding author: irenekartika73@gmail.com

Copyright (c) 2020 THE AUTHOR(S).This article is distributed under a Creative Commons Attribution-Share Alike 4.0 International license. Jurnal Teknosains is published by the Graduate School of Universitas Gadjah Mada. 


\begin{abstract}
Strawberries are one of the horticultural commodities that have high economic value so that it is very potential as a source of farmers' income. Strawberries are fruits that can be consumed fresh, frozen, or made into preparations. The relatively high demand for strawberries hasn't yet to be fulfilled. This condition provides a good opportunity to develop strawberries in Indonesia. So far, the cultivation of strawberries carried out by farmers is still conventional and is cultivated on a small scale. Various aspects that are important for maintaining fruit quality are not done well by farmers. Variable input allocations between farmers result in inefficient production. The objective of this study is to determine the technical efficiency and the factors affecting the technical inefficiency of strawberry farming in Purbalingga Regency. This study was conducted in Karangreja Subdistrict, Purbalingga Regency, Central Java Province. Purposive sampling method was utilized to select 100 farmers as the respondents, all of whom have been running their farm business for at least three years consecutively from 2015 to 2017. Stochastic Frontier production function was applied to measure technical efficiency and factors affecting technical inefficiency. The findings show that strawberry farming in Purbalingga Regency, Central Java Province, is technically efficient with efficiency number varies between $26.50-99.40 \%$ and the average efficiency number of $77.80 \%$. Furthermore, the results indicate that the farmers' formal education and the number of household members significantly affect the technical efficiency of strawberry farming. To improve the efficiency of strawberry farming, it is necessary to improve the knowledge and skills of farmers through counseling, assistance, and training to improve the ability of farmers to manage their business in a professional, efficient and entrepreneurial manner. Mentoring can be provided in groups by government, private, or tertiary institutions.
\end{abstract}

Keywords: Purbalingga Regency; Stochastic Frontier; Strawberry Farming; Technical Efficiency.

\section{INTRODUCTION}

Even though strawberry is not a native plant of Indonesia, it has gained wide popularity in Indonesia and also in the world. The attractiveness of this fruit are its bright color as well as its fresh and distinctive taste and smell. Up to this moment, the high demand for strawberry in Indonesia still cannot be fulfilled by the local production. Based on the information from the Director General of Horticulture, in 2016, the import value of strawberry is US\$1,370,629 with $547.141 \mathrm{~kg}$ in volume, while the export value of strawberry is US\$ 104,007 with $11.281 \mathrm{~kg}$ in volume (Biro Pusat Statistik Jawa Tengah Tengah, 2017). The strawberry imports, either fresh or frozen, appear high in volume. Indonesia is importing strawberries from China, Australia, France, the United States, and Canada.

This situation provides a great opportunity to expand strawberry farmings in Indonesia. Strawberry can grow well in the mountains' cool temperature such as in Karangreja Subdistrict, Purbalingga Regency. Karangreja Subdistrict is situated on 1,0001,800 meters above sea level bearing agro-climate characteristics such as the land covered with latosol, the daily temperature of $22 \mathrm{oC}$, the average rainfall of $3,575 \mathrm{~mm}$ per annum. Those characteristics are suitable for strawberry plantation. Purbalingga Regency is the central production of strawberry in Central Java Province. The cultivated area of strawberry in Purbalingga Regency during three recent years are 12 ha (2014), 20 ha (2015), and 67 ha (2016) with the number production of $635.4 \mathrm{~kg}$ (2014); $457.8 \mathrm{~kg}$ (2015); and 236.1 $\mathrm{kg}$ (2016). The increase of cultivated area that is not balanced by the increase in production will result in the decreasing number of productivity. During 2014 to 2016, the strawberry productivity has decreased from $5.295 \mathrm{~kg} /$ ha to $0.352 \mathrm{~kg} / \mathrm{ha}$ (Biro Pusat Statistik Kabupaten Purbalingga, 2017).

All this while, the strawberry farming practice is still small-scaled and using traditional methods. The farmers often pay little attention to the cultivation techniques, such as watering (irrigation), replanting, raw straw mulching, weeding, subsequent fertilization, pruning, plant protection, so that the quality and quantity of strawberry production cannot be optimized. Many important aspects that ensure the quality of the fruits are not carried out properly by the farmers. Many of them plant the strawberries with the spacing narrower than the ideal spacing method in order to increase the land capac- 
ity. Weeds are often left to grow in between planting beds. The farming areas that relatively small and scattered, the high price of fertilizers and pesticides, together with the high risk of crop failure all contribute to the wide variation of production inputs among farmers. The varied allocations of production inputs can prompt the inefficiency of production among farmers. For this reason, it is crucial to learn the current efficiency values based on the factors affecting it.

Frontier production function has been widely applied in the fields of agriculture, fisheries, to financial economics. One of the advantages of this function compared to other production functions is its ability to analyze the efficiency and inefficiency of a production process technique. This is made possible by the introduction of a standard error that presents the efficiency of the technique into a model that has a default error (Sukiyono, 2004). Research related to the efficiency of various agricultural commodities has been carried out by previous researchers. Following are some of the strawberry studies that have been carried out, including: Tariq et al. 2018 who examine the technical efficiency of strawberries in Pakistan. The analytical method used is the production of the Stochastic Frontier. Production inputs used are land, seeds, manure, NPK fertilizer, pesticides, and labor. While Rahmati, D. et al (2016) examined the production function and technical efficiency of Darreh Shahr wheat producers, the analysis model used was the Cobb-Douglas production function and Stochastic Frontier analysis (SFA). The results showed that the area of land, urea fertilizer, seeds, and dummy irrigation systems had a significant effect on wheat production. Rivanda also examine the a nalysis of the technical efficiency of wetland rice farming (Rivanda et al., 2015). This study aims to analyze the factors that influence the production and technical efficiency level of wetland rice. The data analysis meth od used is the Cobb-Douglas Stochastic Fron tier Production Function which is processed using the Frontier 4.1c application using the Maximum
Likelihood Estimation (MLE) m ethod. The results showed that the variables of land area, NPK fertilizer, manure, labor, planting season, and pesticides each had a positive effect on lowland rice production while the number of seeds had a negative effect. (Rivanda, 2015; Rahmati, 2016; Tariq, 20 18) indicate that production input that is thought to influence the production of a commodity is land area, seeds, manure, chemical fertilizers, pesticides, and labor. Rivanda (2015) and Tariq (2018) did not classify pesticides according to their function, while actually pesticides used by farmers can be classified into fungicides, insecticide and herbicides. In addition, previous research assumes that the types of varieties grown by farmers are considered the same. Whereas farmers gen erally plant different varieties. On this basis, researchers used pesticide variables that were grouped into fungicides and insecticide, and included varieties as dummy variables which were thought to influence the technical efficiency of strawberry farming in Purbalingga Regency. This study aims to analyze the technical efficiency of strawberry farming and the factors affecting technical inefficiency of strawberry farming.

\section{METHOD}

\section{Sample Size and Sampling Methods}

The Purbalingga Regency was chosen because it is the central production of strawberry in Central Java Province. The sampling method used in this study is purposive sampling method. The purposive sampling method is a sample selection method that is the strawberry farmers who are sampled are selected deliberately with criteria that are in line with the research objectives. The sample criteria in this study are farmers who have cultivated strawberries for at least three consecutive years (2015-2017) in Purbalingga Regency. The consideration of determining the number of samples refers to the central boundary theory which states that the sampling distribution of the mean can be assumed to be almost normally distributed even for the most abnormal population when 
the sample size is $n \geq 30$. Thus the determination of a sample of 100 strawberry farmers has met the minimum sample size that can be used to estimate variations in the population of strawberry farmers in Purbalingga Regency. Data collection methods are interviews, observations, and records. Both primary and secondary data are used in this study.

\section{Data Analysis Method}

Technical efficiency according to (Coelli, 1995) is the proportion or ration between observed output (Yi) and estimated output or highest output $\left(\mathrm{Yi}^{*}\right)$ with the technology applied. Technical efficiency of strawberry farming is defined by:

$T E_{i}=\frac{E\left(Y \mid U_{i}, X_{i}\right)}{E\left(Y^{*} \mid U_{i}=0, X_{i}\right)}=E\left[\frac{\exp \left(-U_{i}\right)}{\varepsilon_{i}}\right]$

$\mathrm{TE}_{\mathrm{i}}$ value is somewhere between 0 and 1 or 0 $\leq \mathrm{TE}_{\mathrm{i}} \leq 1$.

where :

$\mathrm{TE}_{\mathrm{i}} \quad$ : technical efficiency for $i$-th farmer

$Y_{i}$ : actual output function (without error term)

$\mathrm{Y}_{\mathrm{i}^{*}} \quad$ : potential output function

$\mathrm{U}_{\mathrm{i}} \quad$ : random variable that decribes technical inefficiency and is only used for function with certain input and output numbers (cross section data).

Cobb Douglass model of stochastic frontier production function that was applied to answer the first aim of this study is strawberry production function of each farmer. The empirical model is defined by:

$\ln Y_{i}=\beta_{0}+\beta_{1} \ln X_{1}+\beta_{2} \ln X_{2}+\beta_{3} \ln X_{3}+\beta_{4} \ln X_{4}$ $+\beta_{5} \ln X_{5}+\beta_{6} \ln X_{6}+\left(v_{i}-u_{i}\right)$

where :

$\mathrm{Yi}$ : strawberry production $(\mathrm{kg})$

$\mathrm{X}_{1}:$ land area $\left(\mathrm{m}^{2}\right)$

$\mathrm{X}_{2}:$ : number of seedlings (stem)

$X_{3}:$ amount of manure $(\mathrm{kg})$
$\mathrm{X}_{4} \quad:$ number of labor $(\mathrm{kg})$

$X_{5}:$ amount of fungicide $(\mathrm{kg})$

$X_{6} \quad:$ amount of insecticide (liter)

$\mathrm{D}_{1}$ : dummy of plant variety $(\mathrm{D}=1$ : Oso

Grande, $\mathrm{D}=0$ : Sweet Charlie)

vi : error term caused by external factors (weather, pests and diseases)

$\mu \mathrm{i} \quad$ : error term caused by internal factors of farmer (technical inefficiency factor in production)

$\beta_{1}-\beta_{6}>0$ : estimated coefficient regression

Aigner et al. (1977) stated that variable $\mu_{i}$ that is used to measure the technical inefficiency effect was assumed to be independent and half-normal distributed. Empirical method used to determine factors affecing technical inefficiency is:

$\mu_{\mathrm{i}}=\delta_{0}+\delta_{1} \ln Z_{1}+\delta_{2} \ln Z_{2}+\delta_{3} \ln Z_{3}+\delta_{4} \ln Z_{4}$

where:

$\mu_{\mathrm{i}} \quad:$ technical inefficiency

$Z_{1} \quad$ : farmer age (year)

$Z_{2} \quad$ : farmer formal education petani (year)

$Z_{3} \quad:$ strawberry farming experience (year)

$Z_{4}$ : number of household member (person)

$\delta_{1}-\delta_{4}:$ estimated coefficient regression $<0$

Parameters from the model above were estimated by Maximum Likelihood (MLE) method and Frontier version 4.1. developed by Coelli (1996). Inefficiency effect of the model above was analyzed by the statistic method according to Battese and Corra (1977) that is maximum Likelihood Estimation (MLE). Data processed with Frontier 4.1. will present the estimated effect variance of the parameters as follows:

$$
\sigma^{2}=\sigma u^{2}+\sigma v^{2} \text { and } \gamma=\sigma u^{2} / \sigma v^{2}
$$

where:

$\sigma^{2} \quad: \quad$ variance of normal distribution

$\sigma \mathrm{u}^{2} \quad$ : variance of $\mathrm{u}^{\mathrm{i}}$

$\mathrm{ov}^{2} \quad$ : variance of $\mathrm{v}^{\mathrm{i}}$ 
Parameter $\gamma$ is the contribution of technical efficiency in residual error $(\varepsilon)$ of which value is ranged from zero to one. Parameter $\gamma$ of which value is closer to zero indicates that frontier deviation closer to residual effect (error), while the value that is closer to one indicates that frontier deviation closer to technical inefficiency effect.

\section{RESULT AND DISCUSSION Stochastic Frontier Production Function of Strawberry Farming}

Based on the farming conditions by the time data was acquired, processed data reveal that land area, the number of seedlings, the amount of manure, the amount of NPK fertilizer, the number of labor, the amount of insecticide and fungicide, and also variety are the production factors affecting strawberry production in Purbalingga Regency. The estimated production function using stochastic frontier is presented in Table 1.

Table 1

Stochastic Frontier Production Function of Strawberry Farming with MLE Method

\begin{tabular}{|c|c|c|c|}
\hline Variable & $\begin{array}{l}\text { Estimated } \\
\text { Sign }\end{array}$ & Coefficient & t-value \\
\hline Intercept & $+/-$ & $1.7052^{*}$ & 1.9416 \\
\hline Land area & + & $0.0002^{*}$ & 1.9883 \\
\hline Seedling & + & $0.4329^{* * *}$ & 4.6876 \\
\hline Labor & + & $0.1692^{* *}$ & 2.1781 \\
\hline Manure & + & $0.0468^{*}$ & 1.8779 \\
\hline NPK Fertilizer & + & $0.04313^{* * *}$ & 3.1947 \\
\hline Fungicide & + & $-0.0574^{* *}$ & -0.5268 \\
\hline Insecticide & + & -0.0036 & -0.2353 \\
\hline $\begin{array}{l}\text { Dummy variable } \\
\text { variety }\end{array}$ & + & 0.0382 & 1.4278 \\
\hline Sigma squared & & $0.5721^{* * *}$ & 5.6887 \\
\hline Gamma & & $0.9998^{* * *}$ & 189.2312 \\
\hline $\begin{array}{l}\text { Log-likelihood } \\
\text { function }\end{array}$ & & 23.3369 & \\
\hline $\begin{array}{l}\text { LR Test of the } \\
\text { sided error }\end{array}$ & & 92.2461 & \\
\hline
\end{tabular}

Source: Field survey, 2017

Table 1 shows three parameters: sigma squared $\left(\sigma^{2}\right)$, gamma $(\gamma)$, log-likelihood function (LLF). Further explanation of each parameter as follows. Parameter value of sigma squared $\left(\sigma^{2}\right)$ for strawberry farming is 0.5721 and significant at 0.01 , in other words, technical inefficiency $\left(\mu_{\mathrm{i}}\right)$ contributes $57.21 \%$ to the production variance of strawberry farming. Parameter value of gamma $(\gamma)$ is 0.9998 and significant at 0.01 , in other words, $99.98 \%$ residual variation in the model is caused by technical inefficiencies that can be controlled by farmers. Meanwhile, the other 0.02 percent is caused by stochastic effect $\left(\mathrm{v}_{\mathrm{i}}\right)$, for example pests and diseases, weather, and the model inaccuracy. This finding indicates that technical inefficiency is the significant factors towards the output variability.

Land area has coefficient regression of 0.0002 so that one percent increase in land area will result in the increas of strawberry production up to 0.0002 percent (ceteris paribus). Land area expansion in Purbalingga Regency is feasible because some areas are still used for growing vegetables, such as leek, carrot, choy sum, cabbage, and potato. The increase of production can be done by increasing land area as supported by previous studies of various comodities, such as Saptana et al.(2011), Amoah et al. (2014), Dolatabadi anGhahremanzadeh (2016), Julie et al.(2017), and Tariq et al. (2018).

Coefficient regression of seedling is 0.4329 . It means the addition of one percent of seedling will increase strawberry production up to 0.4329 percent. The increase of strawberry seedling is feasible by implementing the narrower spacing. In a one-hectare land area, seedlings amount recommended by Indonesian Citrus and Subtropical Fruits Research Institute (ICSFRI) is 40,000 to 80,000 stems. In addition, the average of total seedlings planted by farmers in Purbalingga Regency is 64,341 stems, so there is an opportunity for farmers to add the seedling. The seedling amount has a significant and positive relationship with production. This finding is similar to the studies conducted by Sholeh et al. (2013), Darmansyah et al. (2013), Amoah, et al. (2014), and Gichimu et al. (2015). However, this result differs from Tariq et al. (2018) on strawberry in Pakistan. It was found that seedling amount was insignificant to strawberry production in Pakistan.

Positif value of labor coefficient (0.1692) signify that for one percent increase in la- 
bor will result in 0.1692 percent increase of strawberry production. Labors of strawberry farming in Purbalingga Regency mostly are family members of the farmers. All cultivatio and harvesting activities are performed together, without work differentiation between man and woman. The farmers started working at 7 a.m. and finishing at 3 p.m. Some studies have reported the same finding, e.g. Kurniawan (2010), Suharyanto et al. (2013), Effendy et al.(2013), Banani et al. (2013), and Ambarita et al. (2014). However, other studies, such as Jumiati et al. (2014), and Gichimu et al. (2015) found that the addition of labor will decrease coffee production di Tana Tidung Regency and passion fruit production in Kenya. Thus sufficient and quality labor availability is crucial to increase strawberry production in Purbalingga Regency.

Organic fertilizer used by strawberry farmers is chicken manure. Coefficient regression of manure is 0.1692 that means the addition of one percent of manure will increase strawberry production up to 0.1692 percent. Manure is spread or put inside plant holes at the beginning of land preparation. The average manure applied by farmers is 29.14 tons/ha. This practice is in accordance to ICSFRI recommendation 20-30 tons/ha manure intake for strawberry. This finding is similar to Tahir et al. (2010), Darmansyah et al. (2013), Gichimu et al. (2015), Triyono et al. (2016), and Julie et al. (2017). A similar study conducted by Tariq et al. (2018) in Pakistan shows a different result in which manure application is statistically insignificant to strawberry production.

Coefficient regression for NPK fertilizer application is 0.0468 that means every additional one percent of NPK fertilizer will increase strawberry production as much as 0.0468 percent. Majority farmers use NPK fertilizer for primary and suplementary fertilizer. The proper time and dose of NPK application will increase input efficiency and boost plant health. The same results regarding NPK application are found in Ambarita et al. (2014) on soy in South Lampung and Tariq et al. (2018) on strawberry in Pakistan.
While contradictory results are found in Darmansyah et al. (2013) where NPK application has negative impact on cabbage in Rejang Lebong Regency.

Coefficient regression of fungicide application is -0.0431 meaning when fungicide application is added by one percent, strawberry production will reduce as much as 0.0431 percent. Farmers usually overuse and overdose fungicide (once every 2-3 days) in order to protect their plant from fungal infestation. However, this practice will make the plant withered and may prevent fruit ripening. This finding is consistent with other studies: Tahir et al. (2010), Saptana et al. (2011), Sholeh et al.(2013), Effendy et al. (2013), Suharyanto et al. (2013), Darmansyah et al. (2013), and Sarker et al. (2017).

\section{Technical Efficiency of Strawberry Farming}

Technical efficiency (TE) was analyzed by implementing stochastic frontier production model. Technical efficiency of strawberry farming takes a value between 0 and 1 . The category used in this study is as follows. The farming is inefficient if TE value is smaller than 0.70 , fairly efficient if TE value ranges from 0.70 to 0.89 , and highly efficient if TE value is more than 0.90 . Technical efficiency distribution of strawberry farming in Purbalingga Regency is presented in Table 2.

The findings point out that strawberry farmers in Purbalingga Regency are fairly efficient. Technical efficiency value of strawberry farming in Purbalingga Regency takes range from 0.265 to 0.994 with the average value of 0.778 . Technical efficiency of $77.80 \%$ indicates that most farmers can produce $77.80 \%$ of total production inputs used. In general, the success rate of strawberry farming to reach maximum production is about $77.80 \%$ from its frontier, i.e. maximum production level that could be achieved by combining all resources owned at the prime condition of strawberry farming. It signifies that farmers still have an opportunity to increase their strawberry production up to $22.20 \%$ by improving their technology and managerial 

ANY SURYANTINI \& STOCHASTIC FRONTIER ANALYSIS ON TECHNICAL EFFICIENCY OF ...

skill. The increase in production will raise the farmer's income. Based on data analysis results, $85 \%$ of strawberry farmers in Purbalingga Regency has operated with $70 \%$ technical efficiency. While the others $15 \%$ have technical efficiency below $70 \%$. Thus it can be concluded that majority of strawberry farming in Purbalingga Regency is technically efficient $(0.70-0.89)$.

Table 2

Distribution of Technical Efficiency Value of Strawberry Farming in Purbalingga Regency Year 2017

\begin{tabular}{llll}
\hline \multicolumn{1}{c}{ Technical Efficiency Value } & \multicolumn{1}{c}{ Category } & Total (person) & Percentage (\%) \\
\hline $0.2659-0.3949$ & Inefficient & 15 & 15 \\
$0.7010-0.8997$ & Fairly efficient & 54 & 54 \\
$0.9003-0.9949$ & Highly efficient & 31 & 31 \\
\hline Total & & 100 & 100 \\
\hline Minimum & 0.265 & & \\
Mean & 0.778 & & \\
Maximum & 0.994 & & \\
\hline
\end{tabular}

Source: Field survey, 2017

Some studies stated that horticulture farmers have achieved an efficiency of 0.70 are Sarker et al. (2017) on watermelon in Bangladesh with the average of 0.86 ; Tariq et al. (2018) on strawberry in Pakistan with the average of 0.81 ; Kalule (2013) on banana in Uganda with the average of 0.872; Hossain et al. (2015) on banana in Bangladesh with the average of 0.887 .

Differences in technological knowledge may cause variations in technical efficiency level achieved by farmers. Different technology application, particularly in input usage allocations, can be caused by several factors, such as technological knowledge and skill; farmers capability to acquire production inputs; also the number of household members in working age that correlates with labor input. Distribution of input usage based on strawberry farming efficiency is presented in Table 3.

Table 3

Distribution of Input Usage Based on Technical Efficiency Value of Strawberry Farming in Purbalingga Regency Year 2017

\begin{tabular}{llll}
\hline \multirow{2}{*}{\multicolumn{1}{c}{ Variable }} & \multicolumn{3}{c}{ Technical Efficiency Value } \\
\cline { 2 - 4 } & \multicolumn{1}{c}{ Inefficient } & \multicolumn{1}{c}{ Fairly efficient } & Highly efficient \\
\hline Land area $\left(\mathrm{m}^{2}\right)$ & $1,066.667$ & $1,162.556$ & $1,103.71$ \\
Seedling $(\mathrm{stem})$ & $5,936.000$ & $7,449.000$ & $7,077.000$ \\
Manure $(\mathrm{kg})$ & $4,013.000$ & $3,191.000$ & $2,888.000$ \\
NPK Fertilizer $(\mathrm{kg})$ & 49.000 & 61.000 & 56.000 \\
Fungicide (kg) & 2.400 & 2.090 & 2.573 \\
Insecticide (liters) & 2.103 & 1.227 & 1.668 \\
Labor (man days) & 80.380 & 88.949 & 93.109 \\
\hline
\end{tabular}

Source: Field survey, 2017

Differences in production inputs usage affect production total and farmer income. Distribution of cost, revenue, and income of strawberry farmer based on efficiency value is presented in Table 4. 
Table 4

Distribution of Straberry Farming Income Based on Technical Efficiency Value in Purbalingga Regency Year 2017

\begin{tabular}{llll}
\hline \multirow{2}{*}{ Variable } & \multicolumn{3}{c}{ Technical Efficiency Value } \\
\cline { 2 - 4 } & \multicolumn{1}{c}{ Inefficient } & \multicolumn{1}{c}{ Fairly efficient } & Highly efficient \\
\hline Production $(\mathrm{kg})$ & 966.133 & $1,294.940$ & $1,388.160$ \\
Productivity $(\mathrm{kg} /$ plant) & 0.160 & 0.170 & 0.220 \\
Revenue (Rp) & $24,867,316.670$ & $32,886,101.850$ & $35,574,488.100$ \\
Cost (Rp) & $11,131,335.560$ & $13,491,622.070$ & $12,510,536.290$ \\
Income (Rp) & $13,735,981.110$ & $19,394,479.780$ & $23,064,350.810$ \\
\hline
\end{tabular}

Source: Field survey, 2017

The numbers presented in Table 4 hows that strawberry production in highly efficient farming is larger than the other two categories. With the average of $1,000 \mathrm{~m}^{2}$ per farm, strawberry produced by highly efficient farmers is up to $43.68 \%$ higher than inefficient farmers and $7.19 \%$ higher than fairly efficient farmers. The income of highly efficient farmers is $67.91 \%$ more than inefficient farmers and $18.92 \%$ more than fairly efficient farmers. Highly efficient farmers gain the highest revenue and income because their farm has higher productivity compared to other farms. The variety of strawberry production occurs as a consequence of variations in the technical and managerial skill of farmers. Further analysis to determine technical

inefficiency factors, e.g. farmer managerial skill, is elaborated as follow.

\section{Technical Inefficient Factors}

Factors suspected to affect technical efficiency in each sample were analyzed with technical inefficiency effect model from stochastic frontier production function using Frontier 4.1. If technical inefficiency parameter of a variable has positive value, it means that variable increases technical inefficiency (thus reduce the technical efficiency). On the contrary, if technical inefficiency parameter of a variable has negative value, it means that variable can decrease technical inefficiency (thus increase the technical efficiency). Estimated factors affecting technical inefficiency of strawberry farming are presented in Table 5.

Tabel 5

Estimated Facors Affecting Technical Inefficiency on Strawberry Farming in Purbalingga Regency Year 2017

\begin{tabular}{llll}
\hline \multicolumn{1}{c}{ Variable } & \multicolumn{1}{c}{ Estimated sign } & \multicolumn{1}{c}{ Coefficient } & \multicolumn{1}{c}{ t-value } \\
\hline Intercept & $+/-$ & 1.2958 & 1.2417 \\
Age & - & -0.0097 & -0.8911 \\
Education & - & $-0.1301^{*}$ & -1.7409 \\
Experience & - & 0.1112 & 1.2083 \\
Household members & - & $-0.4904^{* * *}$ & -3.5607 \\
\hline
\end{tabular}

Source: Field survey, 2017

Table 5 indicates hat significant factors towards technical inefficiency of strawberry farming are education and the number of household members. Meanwhile, farmers age and strawberry farming experience do not significantly affect technical inefficiency.
Coefficient value of education is -0.1301 . It has a significant level on strawberry farming technical inefficiency. Negative sign found in formal education shows that the higher education the farmer have will result in lower technical inefficiency level. Therefore exercise becomes more efficient. Formal 
education level of farmers will affect their knowledge, understanding, and wisdom in managing their farm. The higher of education corresponds with the farmers'openness, which in turn, will contribute to their ability to adopt new information as well as technology in agriculture practice, especially with the relation to strawberry. Corresponding to this, some studies in various commodities have come with similar results, e.g. Tariq et al. (2018), Effendy et al. (2013), Banani et al. (2013), Gichimu et al. (2015), Amoah et al. (2014), Rivanda et al. (2015). Thus education is essential for farmers in order to improve their knowledge and decision-making ability regarding technological implementations in their agribusiness.

Coefficient regression of the number of household members is proven to be significant and has a negative relationship with technical inefficiency. It means that an increase in the outpouring of labor will reduce the value of technical inefficiency. Thus, big number of household members promotes technical efficiency by ensuring labor availability. Therefore, the cultivation process (e.g. weeding and pruning) becomes more intensive. The less intensive care of strawberry plants causes decreased productivity. This result are similar with studies conducted by Bahari (2014) and Sarker et al. (2017). However, several other studies, (such as Gichimu et al., 2015; Julie et al.,2017; and Tariq et al.,2018) and found that the number of household members has a significant and positive relationship with technical efficiency.

\section{CONCLUSION}

Based on data analysis, out of eight variables predicted to be relevant to strawberry production frontier, only five variables have a significant and positive relationship with production (i.e. land area, seedling, labor, manure, and NPK fertilizer). In addition, one variable is proven to have a negative relationship with production, i.e. fungicide. The most responsive variable is seedling. Therefore, there is an opportunity to increase strawberry production by increasing both the quality and quantity of seedling.

Strawberry farming model in Purbalingga Regency, Central Java Province is technically efficient with various efficiency number ranging from 26.50 to $99.40 \%$ with the average of $77.80 \%$. Farmer formal education and number of household members affect the technical inefficiency of strawberry farming.

To increase the farmers' knowledge and skills, it can be done in several ways, including: activating farmer groups in the area and encouraging farmers to become part of the farmer group. Counseling and training can be routinely provided through farmer groups by involving states, private and university extensions workers and conducting comparative studies on strawberry cultivation to other more productive areas, such as West Java and East Java.

\section{BIBLIOGRAPHY}

Aigner D.J., Lovell, C.A.K.and Schmidt, P. 1977. "Formulation and Estimation of Stochastic Frontier Production Function Models." Journal of Econometric, $6: 21-37$.

Ambarita, M.M., F.E. Prasmatiwi, and A. Nugraha. 2014. “Analisis Efisiensi Produksi Frontier dan Pendapatan Usahatani Kedelai SL-PTT di Kabupaten Lampung Selatan." Jurnal JIIA, 2 (4) : 348 - 355.

Amoah, S.T., I. A. Debrah and ,R. Abubakari. 2014. "Technical Efficiency of Vegetable Farmers in Peri-Urban Ghana Influence and Effects of Resource Inequalities." American Journal of Agriculture and Forestry, 2 (3) : 79-87

Bahari.2014. "Analisis Efisiensi Teknis Usahatani Padi Sawah Pada Sentra Produksi di Kabupaten Bombana dan Kabupaten Konawe Selatan." Jurnal Agriplus, 24 (1) : 26-35

Banani, A., M. Mustadjah, D. Koestiono, and Syafrial. 2013. "Production Management and Technical Efficiency of Red Onion Farming in Brebes Regency." 
Journal of Basic and Applied Scientific Research, 3 (3) : 85 - 90.

Battese, G.E. and Corra, G.S. 1977. “Estimation of A Production Frontier Model: With Application to The Pastoral Zone of Eastern Australia." Australian Journal of Agricultural Economics, 21 (3): 169 - 179.

Biro Pusat Statistik Kabupaten Purbalingga. 2017. Kecamatan Karangreja Dalam Angka 2017. Purbalingga.(https:// purbalinggakab.bps.go.id)

Biro Pusat Statistik Provinsi Jawa Tengah. 2017. Kabupaten Purbalingga Dalam Angka 2017. Semarang. (https:// jateng.bps.go.id)

Coelli, T.J. 1995. “Recent Developments in Frontier Modelling and Efficiency Measurement." Austalian Journal of Agricultural Economics, 39(3) : 222

Coelli T.J. 1996. A Guide to Frontier Version 4.1: A Computer Program for Stochastic Frontier Production and Cost Function Estimation. University of New England - Armidale. New South Wales: Centre for Efficiency and Productivity Analysis.

Darmansyah, A.N., K. Sukiyono, and S. Sugiarti. 2013. "Analisis Efisiensi Teknis dan Faktor yang Mempengaruhi Efisiensi pada Usahatani Kubis di Desa Talang Belitar Kecamatan Sindang Dataran Kabupaten Rejang Lebong." Agrisep, 12 (2): 177 - 194.

Dolatabadi, S.R., and M. Ghahremanzadeh. 2016. "Measuring The Technical Efficiency of Canola Farmers and Determining the Effective Factors in Tabriz Country, Iran." International Journal of Agricultural Management and Development, 6 (4): 505 - 513.

Effendy, N. Hanani, B. Setiawan, and W. Muhaimin. 2013. "Characteristics of Farmers and Technical Efficiency in Cocoa Farming at Sigi RegencyIndonesia With Approach Stochastic
Frontier Production Function." Journal Economics and Sustainable Development, 4 (13): 154 - 160.

Gichimu, C.K., I. Macharia, and M. Mwangi. 2015. "Factors Affecting Technical Efficiency of Passion Fruit Producers in The Kenya Highlands." Asian Journal Agricultural Extension Sociology, 5(3): 120 - 136.

Hossain, M., A. Alam, and K. Uddin. 2015. "Application of Stochastic Frontier Production Function on Small Banana Growers of Kushtia District in Bangladesh." Journal of Statistics Application E Probability, 4 (2): 337 - 342

Julie, T.N., F.D. Engwali, and B.J. Claude. 2017. "Technical Efficiency of Diversification Versus Spescialization of Vegetable Based Farms in The West Region of Cameroon." American Journal of Agriculture and Forestry, 5 (4) : 112 - 120.

Jumiati, E. and S.I. Mulyani. 2014. "Efisiensi Teknis Usahatani Kopi di Kabupaten Tana Tidung (KTT)." Jurnal Agrifor, $13(2)$ : 155 - 164.

Kalule, S.W. 2013. "Credit Use And Technical Efficiency Among Smallholder Banana Producers in Sheema District Uganda." International Journal of Accounting and Financial Management Research (LJAFMR), 3(4) : 41-52.

Kurniawan, A.Y. 2010. “Faktor-Faktor yang Mempengaruhi Efisiensi Teknis Pada Usahatani Padi Lahan Pasang Surut di Kecamatan Anjir Muara, Kabupaten Barito Kuala Kalimantan Selatan." EPP, 7(2) : 40 - 46.

Rahmati, D., M.J. Saniz and B. Gholami. 2016. "Estimating production function and technical efficiency of wheat producers, Ilam Province, Iran, (Case Study: Darreh Shahr)." Journal Of Current Research In Science, 1 : 591 - 595.

Rivanda, D.R., W. Nahraeni, and A. Yusdiarti. 2015. "Analisis Efisiensi Teknis 
Usahatani Padi Sawah." Jurnal Agrisains, $1(1): 1-13$.

Saptana, A. Daryanto, H.K. Daryanto, and Kuntjoro. 2011. “Analisis Efisiensi Produksi Komoditas Cabai Merah Besar dan Cabai Merah Keriting di Propinsi Jawa Tengah : Pendekatan Fungsi Produksi Frontier Stokastik." Jurnal Forum Pascasarjana, 34(3) : 173 $-184$.

Sarker, B., S. Majumder, and M.A. Khatun. 2017. “Technical Efficiency, Determinant and Risks of Watermelon Production in Bangladesh." IOSR Journal of Economics and Finance (IOSR-JEF), 8 (2) : 51 - 59 .

Sholeh, S., N. Hanani, and Suhartini. 2013. "Analisis Efisiensi Teknis dan Alokatif Usahatani Wortel di Kecamatan Bumiaji Kota Batu." Jurnal Agrise, 13(3) : 232-233

Suharyanto, J.H. Mulyo, D.H. Darwanto, and S. Widodo. 2013. "Analisis Efisiensi Teknis Pengelolaan Tanaman Terpadu (PTT) Padi Sawah di Propinsi Bali." Jurnal SEPA, 9 (2) : $219-230$.
Sukiyono, K. (2004). “Analisa fungsi produksi dan efisiensi teknis (Aplikasi fungsi produksi frontier pada usahatani cabai di Kecamatan Selupu Rejang)." Jurnal Ilmu-Ilmu Pertanian Indonesia, 6 (2) : 104-110.

Tahir, A.G., D.H. Darwanto, J.H. Mulyo, and Jamhari. 2010. "Analisis efisiensi produksi sistem usahatani kedelai di Sulawesi Selatan." Jurnal Agroekonomi, 28(2) : 133 - 151.

Tariq, M., M.K. Hussain, Z.K. Malik, and N. Jehan. 2018. "An estimation of technical efficiency of strawberry production in District Charsadda Khyber Pakhtunkhwa." Sarhad Journal of Agricultura, 34 (1) : 92 - 101.

Triyono, J.H. Mulyo, Masyhuri, and Jamhari. 2016. "Pengaruh karakteristik struktural dan Manajerial Terhadap Efisiensi Usahatani Padi di Kabupaten Sleman. "Jurnal Agraris, 2(1) : $1-8$. 